九州大学学術情報リポジトリ

Kyushu University Institutional Repository

\title{
In Vitro Morphogenesis from Ovaries of Hippeastrum $X$ hybridum
}

Huang, Chieh Li

Horticultural Science, National Chiayi University

Chang, Kuo Cheng

Horticultural Science, National Chiayi University

Okubo, Hiroshi

https://doi.org/10.5109/4617

出版情報：九州大学大学院農学研究院紀要. 50 (1)，pp.19-25，2005-02-01. Faculty of Agriculture， Kyushu University

バージョン :

権利関係 : 


\title{
In Vitro Morphogenesis from Ovaries of Hippeastrum $\mathrm{x}$ hybridum
}

\author{
Chieh Li HUANG ${ }^{1 *}$, Kuo Cheng CHANG ${ }^{1}$ and Hiroshi OKUBO
}

\author{
Laboratory of Horticultural Science, Division of Agricultural Botany, \\ Department of Plant Resources, Faculty of Agriculture, \\ Kyushu University, Fukuoka 812-8581, Japan \\ (Received October 18, 2004 and accepted November 11, 2004)
}

\begin{abstract}
In vitro morphogenensis from ovary-slices of Hippeastrum x hybridum cv. Hermitage was examined. Bulblet formation rates were high with $1 \mathrm{mgl}^{-1}$ and higher concentrations of naphthyl acetic acid (NAA) together with high $\left(1,2\right.$ or $\left.5 \mathrm{mgl}^{-1}\right)$ concentrations of $\mathrm{N}^{i-}$-benzyladenine (BA), and the highest number of bulblets was 5.3 with $5 \mathrm{mgl}^{-1} \mathrm{NAA}+5 \mathrm{mgl}^{-1} \mathrm{BA}$. Somatic embryogenesis was histologically confirmed. High frequency of embryogenesis was obtained with higher concentrations of 2,4-dichlorophenoxyacetic acid $(2,4-\mathrm{D})\left(1-5 \mathrm{mgl}^{-1}\right)+$ thidiazuron (TDZ) $\left(0.02-2 \mathrm{mgl}^{-1}\right)$, which lead the high rates and number of bulblet formation.
\end{abstract}

\section{INTRODUCTION}

Natural asexual propagation rate of Hippeastrum $\mathrm{x}$ hybridum through offsets is low. Twin scaling is the most advanced technique on the propagation of Hippeastrum, Narcissus and other Amaryllidaceae. Since Mii et al. (1974) first achieved the in vitro organogenesis in Hippeastrum x hybridum from scale explants, various organs have been used for in vitro propagation of this species to speed up vegetative propagation. They were scale (Seabrook and Cumming, 1977; Yanagawa and Sakanishi 1977, 1980; Huang et al., 1990; Blakesley and Constantine, 1992), twin scales (Hussey 1975a, 1976a; Huang et al., 1990), flower stem (Hussey 1975a, 1976a; Seabrook and Cumming, 1977), leaf (Hussey, 1976a; Seabrook and Cumming, 1977), ovary (Seabrook and Cumming, 1977) and peduncle (Seabrook and Cumming, 1977).

Ovaries have been often used for micropropagation successfully in many other bulbous species such as Hyacinthus (Hussey, 1975a, b), Lilium (Novak and Petru, 1981), Muscari (Hussey, 1975a), Narcissus (Hussey, 1975a), Ornithogalum (Hussey, 1975a, 1976b) and Scilla (Hussey, 1975a).

Not so many reports are available on somatic embryogenesis in bulbs (Chakravarty and Sen 1987; Gude and Dijkema, 1997; Sage et al., 2000), although it has been pointed out that somatic embryogenesis has the potential as the most effective means of micropropagation of plants (Tisserat et al., 1979). No plantlets were obtained through somatic embryogenesis in Hippeastrum.

In this study, we examined the in vitro morphogenensis from ovary-slices of Hippeastrum $\mathrm{x}$ hybridum to search for more efficient micropropagation methods in this species.

\footnotetext{
1 Horticultural Science, National Chiayi University, 300 University Road, Chiayi, Taiwan

* Corresponding author (Fax: +886-5-271-7427)
} 


\section{MATERIALS AND METHODS}

\section{Plant materials}

Bulbs of Hippeastrum x hybridum cv. Hermitage grown in the fields at National Chiayi University, Chiayi, Taiwan were used. The inflorescences of $15-20 \mathrm{~cm}$ in length were prepared during 6 and 13 April 2004 and surface sterilized with $70 \%$ ethanol for 30 seconds. Ovaries were aseptically taken out and sterilized with $1.5 \% \mathrm{NaOCl}$ for 15 minutes. After rinsing them with sterile distilled water three times, explants were prepared by cutting them in round slices with $0.8-1.0 \mathrm{~mm}$ thickness.

\section{Culture medium}

The explants were placed on MS medium (Murashige and Skoog, 1962) with $30 \mathrm{gl}^{-1}$ sucrose and $2.7 \mathrm{gl}^{-1}$ Gelrite but modified by reducing the concentrations of ammonium nitrate and potassium nitrate to $1 / 4$ and $1 / 2$, respectively from their original concentrations of MS medium. The $\mathrm{pH}$ was adjusted to $5.5-5.7$ before adding the Gelrite, and the medium was autoclaved at $121^{\circ} \mathrm{C}$ for 15 minutes.

\section{Experiments}

Effects of naphthyl acetic acid (NAA) and $\mathrm{N}^{6}$-benzyladenine (BA) and effects of 2,4-dichlorophenoxyacetic acid (2,4-D) and thidiazuron (TDZ) with various combinations of concentrations on morphogenesis and growth were examined.

All cultures were incubated at $25 \pm 2{ }^{\circ} \mathrm{C}$ in darkness for the first one month and then in $16 \mathrm{~h}$ daylength (28-36 $\left.\mu \mathrm{molsec}^{-1} \mathrm{~m}^{-2}\right)$. Each treatment consisted of 15 explants in five glass tubes ( $30 \mathrm{~mm}$ in diameter $\times 150 \mathrm{~mm}$ in height) filled with $10 \mathrm{ml}$ of the medium. Histological observations of the explants took place every two weeks.

\section{RESULTS AND DISCUSSION}

\section{Effects of NAA and BA}

Protuberances were produced in all the treatments, among which the rates were higher with $1 \mathrm{mgl}^{-1}$ and higher concentrations of NAA irrespective of the concentrations of BA (Table 1). Rates of bulblet formation were high with $1 \mathrm{mgl}^{-1}$ and higher concentrations of NAA $+1,2$ or $5 \mathrm{mgl}^{-1} \mathrm{BA}$. No bulblets were obtained with lower $\left(0.1\right.$ or $\left.0 \mathrm{mgl}^{-1}\right) \mathrm{NAA}$ concentration except when $5 \mathrm{mgl}^{-1} \mathrm{BA}$ was added. The highest rates of root formation were observed with $5 \mathrm{mgl}^{-1} \mathrm{NAA}$ with or without the addition of BA. Initiation of protuberances, shoot formation, root initiation and growth are shown in Fig. 1.

Number of bulblets was greatest (5.3) with $5 \mathrm{mgl}^{-1} \mathrm{NAA}+5 \mathrm{mgl}^{-1}$ BA followed by 4.9 in the second position with $5 \mathrm{mgl}^{-1} \mathrm{NAA}+1 \mathrm{mgl}^{-1} \mathrm{BA}$ or $5 \mathrm{mgl}^{-1} \mathrm{NAA}+2 \mathrm{mgl}^{-1} \mathrm{BA}$, but it was not completely reflected the number of protuberances initiated (Table 2). The treatments that resulted in large number of bulblets also brought larger number of leaves and longer leaves. Larger number of roots was obtained with higher NAA concentrations.

The yield of bulblets obtained from ovaries in this study is higher than those of bulblets from twin scales or those of protocorm-like bodies from single scales when compared with our previous results (Huang et al., 1990). Ovaries are considered to be superior explant sources in Hippeastrum to scales. Seabrook and Cumming (1977) 
Table 1. Effect of NAA and BA on morphogenesis from ovaries of Hippeastrum $\mathrm{x}$ hybridum cv. Hermitage.

\begin{tabular}{cccccc}
\hline \multicolumn{2}{c}{ Treatment $\left(\mathrm{mgl}^{-1}\right)$} & $\begin{array}{c}\text { Protuberance } \\
\text { formation (\%) }\end{array}$ & $\begin{array}{c}\text { Bulblet } \\
\text { formation (\%) }\end{array}$ & $\begin{array}{c}\text { Root } \\
\text { formation (\%) }\end{array}$ & $\begin{array}{c}\text { Browning } \\
(\%)\end{array}$ \\
\hline 0 & 0 & 60 & 0 & 0 & 47 \\
0 & 0.1 & 60 & 0 & 0 & 33 \\
0 & 1 & 60 & 0 & 0 & 27 \\
0 & 2 & 67 & 0 & 0 & 40 \\
0 & 5 & 87 & 20 & 0 & 13 \\
0.1 & 0 & 40 & 0 & 0 & 60 \\
0.1 & 0.1 & 73 & 0 & 0 & 27 \\
0.1 & 1 & 87 & 0 & 0 & 13 \\
0.1 & 2 & 73 & 0 & 0 & 27 \\
0.1 & 5 & 67 & 0 & 0 & 13 \\
1 & 0 & 80 & 47 & 20 & 13 \\
1 & 0.1 & 87 & 40 & 20 & 7 \\
1 & 1 & 67 & 100 & 0 & 0 \\
1 & 2 & 100 & 93 & 40 & 0 \\
1 & 5 & 100 & 100 & 7 & 0 \\
2 & 0 & 100 & 7 & 27 & 0 \\
2 & 0.1 & 93 & 13 & 60 & 0 \\
2 & 1 & 80 & 53 & 27 & 0 \\
2 & 2 & 100 & 100 & 46 & 0 \\
2 & 5 & 100 & 100 & 0 & 0 \\
5 & 0 & 100 & 47 & 100 & 0 \\
5 & 0.1 & 83 & 40 & 60 & 0 \\
5 & 1 & 100 & 100 & 46 & 0 \\
5 & 2 & 100 & 93 & 100 & 0 \\
5 & 5 & 100 & 100 & 67 & 0 \\
\hline
\end{tabular}
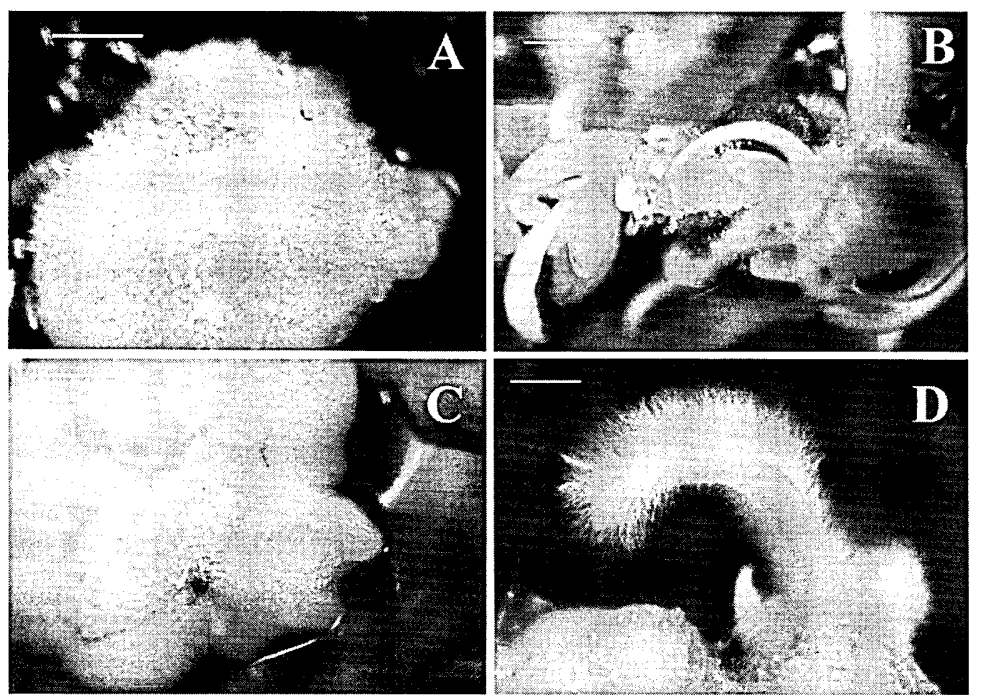

Fig. 1. Morphogenesis from ovary explant of Hippeastrum x hybridum cv. Hermitage with NAA and BA. A; protuberances, B; shoots, C; root primordia, D; roots. Bars $=3 \mathrm{~mm}$. 
Table 2. Effect of NAA and BA on morphogenesis from ovaries of Hippeastrum x hybridum $\mathrm{cv}$. Hermitage.

\begin{tabular}{|c|c|c|c|c|c|c|}
\hline \multicolumn{2}{|c|}{ Treatment $\left(\mathrm{mgl}^{-1}\right)$} & \multirow{2}{*}{$\begin{array}{c}\text { No. of } \\
\text { protuberances/ } \\
\text { explant }\end{array}$} & \multirow{2}{*}{$\begin{array}{l}\text { No. of } \\
\text { bulblets/ } \\
\text { explant }\end{array}$} & \multirow{2}{*}{$\begin{array}{l}\text { No. of } \\
\text { leaves/ } \\
\text { explant }\end{array}$} & \multirow{2}{*}{$\begin{array}{l}\text { Length of } \\
\text { leaves (mm) }\end{array}$} & \multirow{2}{*}{$\begin{array}{l}\text { No. of roots/ } \\
\text { explant }\end{array}$} \\
\hline NAA & $\mathrm{BA}$ & & & & & \\
\hline 0 & 0 & $1.9 \mathrm{fgh} *$ & 0 & 0 & - & 0 \\
\hline 0 & 0.1 & $1.9 \mathrm{fgh}$ & 0 & 0 & - & 0 \\
\hline 0 & 1 & $1.8 \mathrm{gh}$ & 0 & 0 & - & 0 \\
\hline 0 & 2 & $3.5 \mathrm{defg}$ & 0 & 0 & - & 0 \\
\hline 0 & 5 & $4.1 \mathrm{cde}$ & $0.3 \mathrm{~g}$ & 0 & - & 0 \\
\hline 0.1 & 0 & $1.6 \mathrm{~h}$ & 0 & 0 & - & 0 \\
\hline 0.1 & 0.1 & $2.9 \mathrm{efgh}$ & 0 & 0 & - & 0 \\
\hline 0.1 & 1 & $1.8 \mathrm{fgh}$ & 0 & 0 & - & 0 \\
\hline 0.1 & 2 & $2.9 \mathrm{efgh}$ & 0 & 0 & - & 0 \\
\hline 0.1 & 5 & $2.5 \mathrm{efgh}$ & 0 & 0 & - & 0 \\
\hline 1 & 0 & $4.1 \mathrm{cde}$ & $0.9 \mathrm{fg}$ & $0.7 \mathrm{cde}$ & $0.1 \mathrm{~d}$ & 0.6 ef \\
\hline 1 & 0.1 & $3.2 \mathrm{efgh}$ & $1.5 \mathrm{efg}$ & 0.8 cde & $0.1 \mathrm{~d}$ & $1.1 \mathrm{def}$ \\
\hline 1 & 1 & $6.9 \mathrm{ab}$ & 2.7 cde & $1.8 \mathrm{bcd}$ & $0.2 \mathrm{~cd}$ & 0 \\
\hline 1 & 2 & $5.1 \mathrm{bcd}$ & $2.2 \mathrm{def}$ & $1.9 \mathrm{bc}$ & $0.6 \mathrm{~b}$ & $2.8 \mathrm{bc}$ \\
\hline 1 & 5 & $6.8 \mathrm{ab}$ & $3.8 \mathrm{abc}$ & $2.8 \mathrm{ab}$ & $0.3 c$ & $0.1 \mathrm{f}$ \\
\hline 2 & 0 & $2.8 \mathrm{efgh}$ & $0.1 \mathrm{~g}$ & $0.1 \mathrm{e}$ & $0.1 \mathrm{~d}$ & $2.5 \mathrm{bcd}$ \\
\hline 2 & 0.1 & $1.9 \mathrm{fgh}$ & $0.1 \mathrm{~g}$ & $0.1 \mathrm{e}$ & $0.1 \mathrm{~d}$ & $2.9 \mathrm{bc}$ \\
\hline 2 & 1 & $3.2 \mathrm{efgh}$ & $1.3 \mathrm{efg}$ & $0.6 \mathrm{de}$ & $0.1 \mathrm{~d}$ & 1.3 cdef \\
\hline 2 & 2 & $5.8 \mathrm{abc}$ & $3.6 \mathrm{bcd}$ & $2.7 \mathrm{~b}$ & $1.2 \mathrm{a}$ & $1.9 \mathrm{cde}$ \\
\hline 2 & 5 & 3.9 de & $3.9 \mathrm{abc}$ & $2.7 \mathrm{ab}$ & $0.7 \mathrm{~b}$ & 0 \\
\hline 5 & 0 & $6.0 \mathrm{ab}$ & $1.2 \mathrm{efg}$ & $0.5 \mathrm{de}$ & $0.1 \mathrm{~d}$ & $3.7 \mathrm{~b}$ \\
\hline 5 & 0.1 & $3.7 \mathrm{def}$ & $0.6 \mathrm{~g}$ & $0.3 \mathrm{e}$ & $0.1 \mathrm{de}$ & $2.1 \mathrm{bcde}$ \\
\hline 5 & 1 & $7.5 \mathrm{a}$ & $4.9 \mathrm{ab}$ & $3.0 \mathrm{ab}$ & $0.2 \mathrm{~cd}$ & $1.1 \mathrm{def}$ \\
\hline 5 & 2 & $2.5 \mathrm{efgh}$ & $4.9 \mathrm{ab}$ & $0.5 \mathrm{e}$ & $0.1 \mathrm{~d}$ & $5.7 \mathrm{a}$ \\
\hline 5 & 5 & $6.1 \mathrm{ab}$ & $5.3 \mathrm{a}$ & $3.9 \mathrm{a}$ & $0.7 \mathrm{~b}$ & 1.8 cde \\
\hline
\end{tabular}

* Values followed by different letters are significantly different at $5 \%$ level.

reported the shoot formation from ovary tissues of Hippeastrum at $4.0 \mathrm{mgl}^{-1} \mathrm{BA}+2.0$ (or $2.4 ; 2.0$ in the text, but 2.4 in Table) $\mathrm{mgl}^{-1} \mathrm{NAA}$ or $4.0 \mathrm{mgl}^{-1} \mathrm{BA}+4.0 \mathrm{mgl}^{-1} \mathrm{NAA}$, similarly to our results. In their results, callus formation was also observed from the ovaries with $4.0 \mathrm{mgl}^{-1} \mathrm{BA}+2.0 \mathrm{mgl}^{-1} \mathrm{NAA}$, whereas there was not in the current experiment.

\section{Effects of 2,4-D and TDZ}

Embryogenesis occurred with high rates with higher concentrations of 2,4-D (1-5 $\left.\mathrm{mgl}^{-1}\right)$ and TDZ $\left(0.02-2 \mathrm{mgl}^{-1}\right)$ although shoot primordium formation was observed in any treatment (Tables 3 and 4). Accordingly the formation rates and number of bulblets were also higher with higher concentrations of 2,4-D and TDZ. However, higher concentrations of TDZ or lower concentrations of 2,4-D inhibited root formation and growth.

The developmental process from somatic embryo initiation to bulblets through globular and cotyledonous embryos is shown in Fig. 2. Somatic embryogenesis was confirmed by the histological observation. Vascular bundle connection was observed between the explant and newly formed organs in adventitious shoot initiation (Fig. 3A), 
Table 3. Effect of 2,4-D and TDZ on morphogenesis from ovaries of Hippeastrum $\mathrm{x}$ hybridum cv. Hermitage.

\begin{tabular}{|c|c|c|c|c|c|c|}
\hline \multicolumn{2}{|c|}{ Treatment $\left(\mathrm{mgl}^{-1}\right)$} & \multirow{2}{*}{$\begin{array}{c}\text { Shoot } \\
\text { primordium } \\
\text { formation (\%) }\end{array}$} & \multirow{2}{*}{$\begin{array}{c}\text { Embryogenesis } \\
\text { (\%) }\end{array}$} & \multirow{2}{*}{$\begin{array}{c}\text { Bulblet } \\
\text { formation } \\
(\%)\end{array}$} & \multirow{2}{*}{$\begin{array}{c}\text { Root } \\
\text { formation } \\
(\%)\end{array}$} & \multirow{2}{*}{$\begin{array}{c}\text { Browning } \\
(\%)\end{array}$} \\
\hline $2,4-D$ & TDZ & & & & & \\
\hline 0 & 0 & 53 & 0 & 33 & 0 & 33 \\
\hline 0 & 0.002 & 80 & 0 & 27 & 0 & 13 \\
\hline 0 & 0.02 & 53 & 0 & 0 & 0 & 33 \\
\hline 0 & 0.2 & 87 & 80 & 93 & 0 & 13 \\
\hline 0 & 2 & 93 & 27 & 60 & 0 & 7 \\
\hline 0.1 & 0 & 80 & 0 & 20 & 0 & 20 \\
\hline 0.1 & 0.002 & 87 & 0 & 0 & 0 & 13 \\
\hline 0.1 & 0.02 & 93 & 0 & 0 & 0 & 7 \\
\hline 0.1 & 0.2 & 93 & 0 & 0 & 0 & 7 \\
\hline 0.1 & 2 & 100 & 53 & 87 & 0 & 0 \\
\hline 1 & 0 & 93 & 53 & 7 & 40 & 7 \\
\hline 1 & 0.002 & 100 & 67 & 33 & 40 & 0 \\
\hline 1 & 0.02 & 100 & 60 & 87 & 33 & 0 \\
\hline 1 & 0.2 & 100 & 80 & 80 & 0 & 0 \\
\hline 1 & 2 & 93 & 100 & 100 & 0 & 0 \\
\hline 2 & 0 & 93 & 0 & 27 & 20 & 7 \\
\hline 2 & 0.002 & 87 & 27 & 33 & 13 & 0 \\
\hline 2 & 0.02 & 87 & 33 & 20 & 40 & 0 \\
\hline 2 & 0.2 & 87 & 100 & 100 & 0 & 0 \\
\hline 2 & 2 & 100 & 73 & 93 & 0 & 0 \\
\hline 5 & 0 & 93 & 67 & 93 & 13 & 7 \\
\hline 5 & 0.002 & 93 & 0 & 33 & 0 & 13 \\
\hline 5 & 0.02 & 100 & 73 & 27 & 0 & 0 \\
\hline 5 & 0.2 & 100 & 100 & 53 & 27 & 0 \\
\hline 5 & 2 & 100 & 33 & 60 & 7 & 0 \\
\hline
\end{tabular}

but not in somatic embryogenesis (Fig. 3B).

The possibility of plantlet regeneration through somatic embryos from ovaries of Hippeastrum was shown in this study, although the bulblet yields were not so higher from somatic embryos than from adventitious bulblet formation. Improvement of the methods for embryogenesis is required.

\section{REFERENCES}

Blakesley, D. and D. Constantine 1992 Uptake and metabolism of 6-benzyladenine in shoot cultures of a range of species. Plant Cell, Tiss. Org. Cult., 28: 183-186

Chakravarty, B. and S. Sen 1987 In vitro generation from callus culture of Scilla indica (Roxb.) Baker. Cur. Sci., 56: $960-962$

Gude, H. and M. H. G. E. Dijkema 1997 Somatic embryogenesis in tulip. Acta Hortic., 430: 275-280

Huang, C. W., H. Okubo and S. Uemoto 1990 Comparison of bulblet formation from twin scales and single scales in Hippeastrum hybridum cultured in vitro. Scientia Hortic., 42: 151-160

Hussey, G. 1975a Totipotency in tissue explants and callus of some members of Liliaceae, Iridaceae, and Amaryllidaceae. J. Exp. Bot., 26: 253-262

Hussey, G. 1975b Propagation of hyacinths by tissue culture. Scientia Hortic., 3: 21-28

Hussey, G. $1976 \mathrm{a}$ In vitro release of axillary shoots from apical dominance in monocotyledonous plantlets. Ann. Bot., 40: 1323-1325 
Table 4. Effect of 2,4-D and TDZ on morphogenesis from ovaries of Hippeastrum $\mathrm{x}$ hybridum cv. Hermitage.

\begin{tabular}{|c|c|c|c|c|c|c|}
\hline \multicolumn{2}{|c|}{ Treatment $\left(\mathrm{mgl}^{-1}\right)$} & \multirow{2}{*}{$\begin{array}{c}\text { No. of shoot } \\
\text { primordia/ } \\
\text { explant }\end{array}$} & \multirow{2}{*}{$\begin{array}{c}\text { No. of somatic } \\
\text { embryos/ } \\
\text { explant }\end{array}$} & \multirow{2}{*}{$\begin{array}{c}\text { No. of } \\
\text { bulblets/ } \\
\text { explant }\end{array}$} & \multirow{2}{*}{$\begin{array}{l}\text { No. of } \\
\text { leaves/ } \\
\text { explant }\end{array}$} & \multirow{2}{*}{$\begin{array}{c}\text { No. of roots/ } \\
\text { explant }\end{array}$} \\
\hline $2,4-\mathrm{D}$ & TDZ & & & & & \\
\hline 0 & 0 & $2.2 j^{*}$ & 0 & $0.5 \mathrm{defg}$ & 0 & 0 \\
\hline 0 & 0.002 & 3.2 hij & 0 & $0.1 \mathrm{~g}$ & 0 & 0 \\
\hline 0 & 0.02 & $2.5 \mathrm{j}$ & 0 & 0 & 0 & 0 \\
\hline 0 & 0.2 & 4.4 efghij & $4.4 \mathrm{abc}$ & $3.9 \mathrm{ab}$ & $0.9 \mathrm{ab}$ & 0 \\
\hline 0 & 2 & $3.3 \mathrm{hij}$ & $0.3 \mathrm{f}$ & 1.0 cdefg & 0 & 0 \\
\hline 0.1 & 0 & $2.7 \mathrm{ij}$ & 0 & $0.3 \mathrm{fg}$ & 0 & 0 \\
\hline 0.1 & 0.002 & $2.9 \mathrm{ij}$ & 0 & 0 & 0 & 0 \\
\hline 0.1 & 0.02 & 4.2 fghij & 0 & 0 & 0 & 0 \\
\hline 0.1 & 0.2 & $3.1 \mathrm{ij}$ & 0 & 0 & 0 & 0 \\
\hline 0.1 & 2 & 4.7 efghi & $1.9 \mathrm{def}$ & $1.3 \mathrm{cdefg}$ & 0 & 0 \\
\hline 1 & 0 & $3.0 \mathrm{ij}$ & $1.0 \mathrm{ef}$ & $0.1 \mathrm{~g}$ & 0 & $1.7 \mathrm{ab}$ \\
\hline 1 & 0.002 & 3.6 ghij & 2.4 cde & $0.6 \mathrm{defg}$ & 0 & $2.6 \mathrm{a}$ \\
\hline 1 & 0.02 & 6.2 cde & $1.3 \mathrm{def}$ & 2.1 bcdef & 0 & $1.1 \mathrm{bc}$ \\
\hline 1 & 0.2 & $7.7 \mathrm{bcd}$ & $3.1 \mathrm{bcd}$ & $1.6 \mathrm{cdefg}$ & 0 & 0 \\
\hline 1 & 2 & $5.5 \mathrm{efg}$ & $5.3 \mathrm{a}$ & $2.4 \mathrm{abcd}$ & 0 & 0 . \\
\hline 2 & 0 & $3.3 \mathrm{hij}$ & 0 & $0.3 \mathrm{fg}$ & 0 & 0.6 cde \\
\hline 2 & 0.002 & 4.0 fghij & $0.4 \mathrm{ef}$ & $0.5 \mathrm{defg}$ & 0 & 0.3 cde \\
\hline 2 & 0.02 & 5.9 def & $0.5 \mathrm{ef}$ & $0.4 \mathrm{efg}$ & 0 & 0.9 bcde \\
\hline 2 & 0.2 & $8.5 \mathrm{ab}$ & $4.9 \mathrm{ab}$ & $4.1 \mathrm{a}$ & $0.8 \mathrm{ab}$ & 0 \\
\hline 2 & 2 & $8.7 \mathrm{ab}$ & $1.5 \mathrm{def}$ & $2.8 \mathrm{abc}$ & $0.9 \mathrm{ab}$ & 0 \\
\hline 5 & 0 & $5.1 \mathrm{efgh}$ & $1.9 \mathrm{def}$ & $2.3 \mathrm{abcd}$ & 0 & 0.2 cde \\
\hline 5 & 0.002 & $2.6 \mathrm{j}$ & 0 & $0.5 \mathrm{defg}$ & 0 & 0 \\
\hline 5 & 0.02 & 3.8 ghij & $2.0 \mathrm{def}$ & $0.1 \mathrm{~g}$ & $1.3 \mathrm{a}$ & 0 \\
\hline 5 & 0.2 & $10.2 \mathrm{a}$ & $4.1 \mathrm{abc}$ & $1.1 \mathrm{cdefg}$ & $0.3 \mathrm{bc}$ & $0.9 \mathrm{bcd}$ \\
\hline 5 & 2 & $8.0 \mathrm{bc}$ & 0.5 ef & $1.3 \mathrm{cdefg}$ & $0.8 \mathrm{ab}$ & $0.1 \mathrm{de}$ \\
\hline
\end{tabular}

* Values followed by different letters are significantly different at $5 \%$ level.

Hussey, G. 1976b Plantlet regeneration from callus and parent tissue in Ormithogalum thyrsoides. J. Exp. Bot., 27: 375-382

Mii, M., T. Mori and N. Iwase 1974 Organ formation from the excised bulb scales of Hippeastrum hybridum in vitro. J. Hort. Sci., 45: 241-244

Murashige, T. and F. Skoog 1962 A revised medium for rapid growth and bioassays with tobacco tissue cultures. Physiol. Plant., 15: 473-497

Novak, F. J. and E. Petru 1981 Tissue culture propagation of Lilium hybrids. Scientia Hortic., 14: 191-199

Sage, D. O., J. Lynn and N. Hammatt 2000 Somatic embryogenesis in Narcissus pseudonarcissus cvs. Golden Harvest and St. Keverne. Plant Sci., 150: 209-216

Seabrook, J. E. A. and B. G. Cumming 1977 The in vitro propagation of amaryllis (Hippeastrum spp. hybrids). In Vitro, 13: 831-836

Tisserat, B., E. B. Esan and T. Murashige 1979 Somatic embryogenesis in angiosperms. Hort. Rev., 1: 1-78

Yanagawa, T. and Y. Sakanishi 1977 Regeneration of bulblets on Hippeastrum bulb segments excised from various parts of a parent bulb. J. Japan. Soc. Hort. Sci., 46: 250-260

Yanagawa, T. and Y. Sakanishi 1980 Regenerative studies on the excised bulb tissue of various tunicated-bulbous ornamentals, II. Morphological observations on bulblet formation from bulb-scale segments. J. Japan. Soc. Hort. Sci., 49: 119-126 

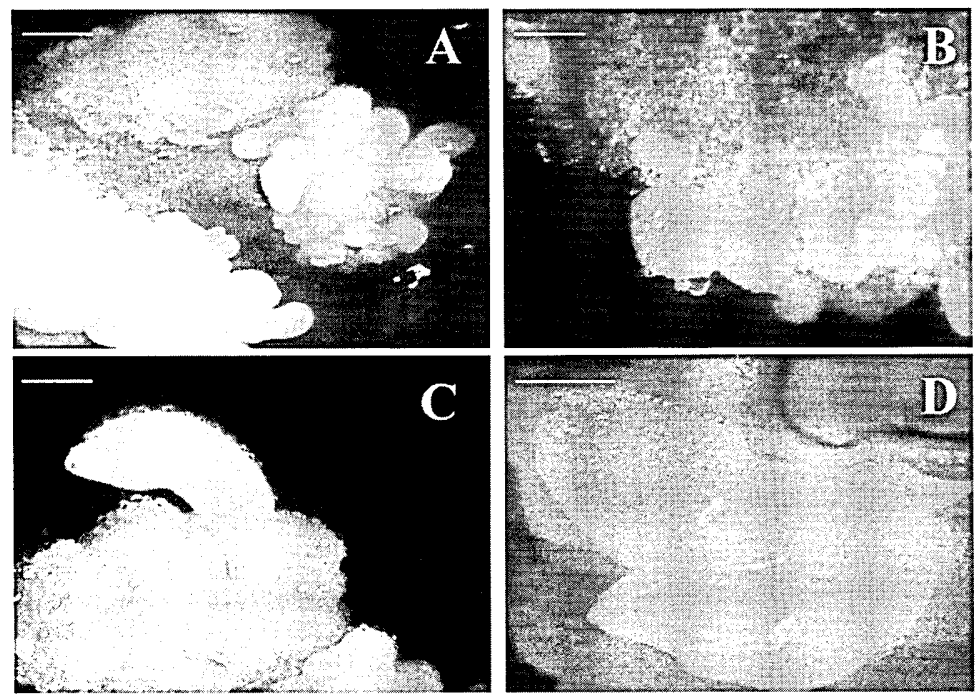

Fig. 2. Bulblet formation from somatic embryos from ovary explant of Hippeastrum $\mathrm{x}$ hybridum cv. Hermitage with 2,4-D and TDZ. A; somatic embryos, B; globular shaped embryos, C; cotyledonous embryos, $\mathrm{D}$; bulblet formation. Bars $=1 \mathrm{~mm}$.
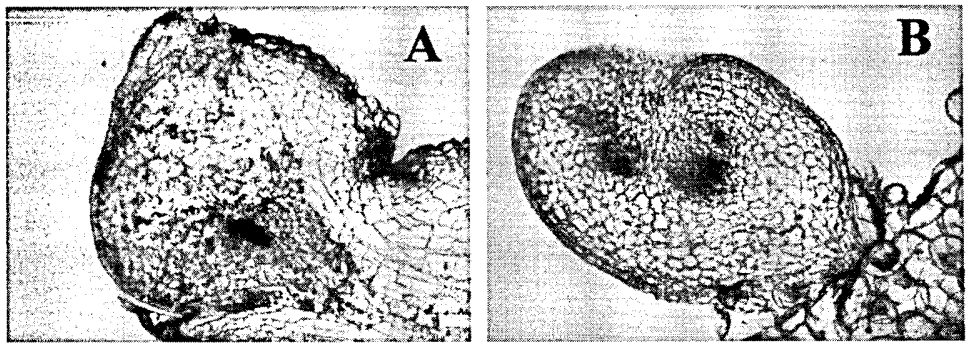

Fig. 3. Histological observation of adventitious shoot differentiation (A) and somatic embryogenesis (B) from ovary explants of Hippeastrum $\mathrm{x}$ hybridum cv. Hermitage. Vascular bundle connection was seen in A, whereas it was not in B. Bars $=300 \mu \mathrm{m}$. 